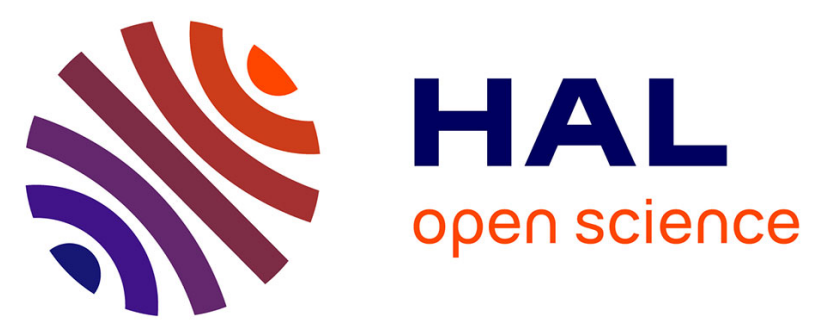

\title{
BRAF mutation in overlapping forms of Erdheim-Chester and Rosai-Dorfman diseases: A unique case restricted to the central nervous system
} Juliette Dufour, Bertrand Mathon, Mehdi Touat, Khê Hoang-Xuan, Karima Mokhtari, Ahmed Idbaih

\section{To cite this version:}

Juliette Dufour, Bertrand Mathon, Mehdi Touat, Khê Hoang-Xuan, Karima Mokhtari, et al.. BRAF mutation in overlapping forms of Erdheim-Chester and Rosai-Dorfman diseases: A unique case restricted to the central nervous system. Revue Neurologique, 2021, 177 (6), pp.708-710. 10.1016/j.neurol.2020.09.010 . hal-03429481

\section{HAL Id: hal-03429481 \\ https: / hal.sorbonne-universite.fr/hal-03429481}

Submitted on 15 Nov 2021

HAL is a multi-disciplinary open access archive for the deposit and dissemination of scientific research documents, whether they are published or not. The documents may come from teaching and research institutions in France or abroad, or from public or private research centers.
L'archive ouverte pluridisciplinaire HAL, est destinée au dépôt et à la diffusion de documents scientifiques de niveau recherche, publiés ou non, émanant des établissements d'enseignement et de recherche français ou étrangers, des laboratoires publics ou privés. 
BRAF mutation in overlapping forms of Erdheim-Chester and Rosai-Dorfman diseases: A unique case restricted to the central nervous system

Juliette Dufour ${ }^{1}$, Bertrand Mathon ${ }^{2}$, Mehdi Touat ${ }^{1}$, Khê Hoang-Xuan ${ }^{1}$, Karima Mokhtari ${ }^{3}$, Ahmed Idbaih ${ }^{1}$

\section{Affiliations}

${ }^{1}$ Sorbonne Université, Inserm, CNRS, UMR S 1127, Institut du Cerveau et de la Moelle épinière, ICM, AP-HP, Hôpitaux Universitaires La Pitié Salpêtrière - Charles Foix, Service de Neurologie 2-Mazarin, F-75013, Paris, France

2Sorbonne Université, AP-HP, Hôpitaux Universitaires La Pitié Salpêtrière - Charles Foix, Service de Neurochirurgie, F-75013, Paris, France

${ }^{3}$ Sorbonne Université, Inserm, CNRS, UMR S 1127, Institut du Cerveau et de la Moelle épinière, ICM, AP-HP, Hôpitaux Universitaires La Pitié Salpêtrière - Charles Foix, Service de Neuropathologie, Paris, F-75013, France

\section{Correspondence}

Pr. Ahmed Idbaih, ahmed.idbaih@aphp.fr 


\section{BRAF mutation in overlapping forms of Erdheim-Chester and Rosai-Dorfman diseases: A unique case restricted to the central nervous system}

A 48-year-old man with a history of pleural tuberculosis presented in 2019 with paraesthesia of the left hemiface. The clinical examination was consistent with a fifth cranial nerve involvement. A brain MRI revealed three hyper-FLAIR and contrast enhanced lesions in the left cerebellar peduncle, the left temporal lobe and the left occipital lobe. Perfusion images showed no hyperperfusion, and spectroscopy revealed a tumour profile, with a pick of choline and low NAA. A whole-body CT scan, PET CT scan, spinal MRI, CSF analysis and blood tests were normal, leading to the conclusion of an isolated brain disease. Therefore, a biopsy of the left temporal lesion was performed to differentiate the three main diagnostic hypotheses: 1) infectious (tuberculosis), 2) inflammatory (neurosarcoïdosis, neuro-Behcet) and 3) tumoral (primary CNS lymphoma) disease. The immunohistopathological examination showed an infiltration with foamy non-Langerhans cell histiocytosis (LCH) cells CD68+, S100+ and CD1a-. Interestingly, pathological analysis found emperipolesis lesions, an uncommon biological process in which a cell penetrates another living cell (which remains intact), unlike phagocytosis, where the inside cell is killed. In addition, immunostaining and tumour sequencing detected a BRAF (V600E) mutation. These results argued for an Erdheim-Chester disease (ECD) BRAF-mutant but with emperipolesis lesions. Our patient was treated with cladribine (2-CDA) and demonstrated a favorable clinical outcome and stable disease on MRI at six months.

Histiocytoses are inflammatory hemopathies characterized by abnormal accumulation of tumour cells derived from macrophages, dendritic and monocyte lineage. The incidence is inferior to five cases per million population [1]. A revised classification has been published in 2016, classifying histiocytoses in five different groups. CNS involvement is most common in (i) group $L$ (Langerhans-related), with LCH and ECD, and (ii) group R, with Rosai-Dorfman-Destombes disease (RDD) [2]. Mitogen-activated protein (MAP) kinase pathway mutations have been demonstrated as key oncogenic drivers in these entities. The most common mutation is BRAF 
mutation, observed in up to $60 \%$ of cases of $\mathrm{LCH}$ and ECD. However, it is exceptional in RDD. Emperipolesis of histiocytes is known to be a hallmark feature of RDD.

Our case corresponds to atypical histiocytosis with BRAF mutation and emperipolesis lesions, raising the question of three possible entities: (i) ECD BRAF mutations with emperipolesis, described in only one previous case report involving the heart [3], (ii) RDD with BRAF mutation reported in three literature cases and (iii) mixed form with ECD and RDD overlap. A recent study described overlap forms, but they were outside the CNS and BRAF wild type [4].

The second interest is that our case represents an isolated CNS involvement. Indeed, histiocytoses are systemic diseases that affect usually skeletal, cardiovascular, endocrine and pulmonary systems. CNS involvement in histiocytosis occurs in $5 \%$ of $\mathrm{LCH}$ and RDD cases and up to $60 \%$ in ECD cases. Isolated CNS involvement is even rarer and must be better understood by neurologists for accurate diagnosis. Indeed, histiocytosis must be promptly considered regarding undetermined brain lesions.

To conclude, our patient represents a unique case of non-LCH with BRAF mutation and emperipolesis, restricted to CNS.

\section{REFERENCES}

[1] Goyal G, Young JR, Koster MJ, Tobin WO, Vassallo R, Ryu JH, et al. The Mayo Clinic Histiocytosis Working Group Consensus Statement for the Diagnosis and Evaluation of Adult Patients With Histiocytic Neoplasms: Erdheim-Chester Disease, Langerhans Cell Histiocytosis, and Rosai-Dorfman Disease. Mayo Clin Proc 2019;94:2054-71. https://doi.org/10.1016/j.mayocp.2019.02.023.

[2] Emile J-F, Abla O, Fraitag S, Horne A, Haroche J, Donadieu J, et al. Revised classification of histiocytoses and neoplasms of the macrophage-dendritic cell lineages. Blood 2016;127:2672-81. https://doi.org/10.1182/blood-2016-01-690636.

[3] Zhu P, Li N, Yu L, Miranda MN, Wang G, Duan Y. Erdheim-Chester Disease with Emperipolesis: A Unique Case Involving the Heart. Cancer Res Treat 2017;49:553-8. https://doi.org/10.4143/crt.2016.078. 
[4] Goyal G, Ravindran A, Young JR, Shah MV, Bennani NN, Patnaik MM, et al. Clinicopathological features, treatment approaches, and outcomes in Rosai-Dorfman disease. Haematologica 2020;105:348-57. https://doi.org/10.3324/haematol.2019.219626.

\section{LEGENDS}

Figure 1. Brain MRI showing hyperintensities in the left cerebellar peduncle, the left temporal lobe and the occipital lobe in FLAIR-weighted MRI signals $(A, B, C)$ and homogeneous contrast enhancement of the cerebellar and temporal lesions on T1-weighted images with gadolinium (D). Histopathological features with infiltration of foamy histiocytes (E), emperipolesis lesions (arrow), which are large histiocytes with intracytoplasmic lymphocytes (F) and BRAF (V600E) positive immunostaining $(G)$.

\section{ACKNOWLEGMENTS}

The program Investissements d'avenir" ANR-10-IAIHU-06. Institut Universitaire de Cancérologie Sorbonne Université. INCA-DGOS-Inserm_12560 Le SiRIC CURAMUS bénéficie du soutien financier apporté par l'Institut National du Cancer, le Ministère des Solidarités et de la Santé et l'Inserm. Centre de référence des histiocytoses. 


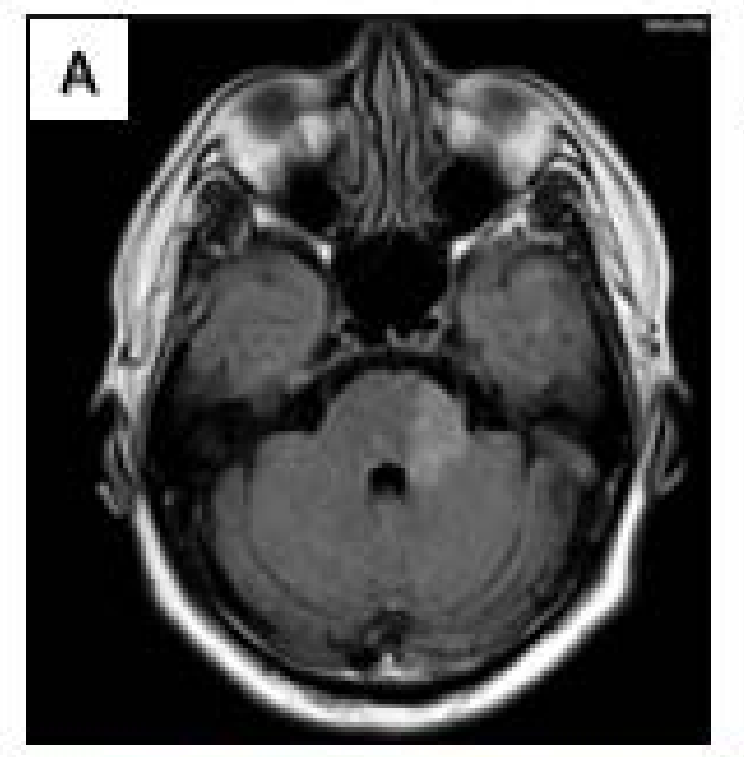

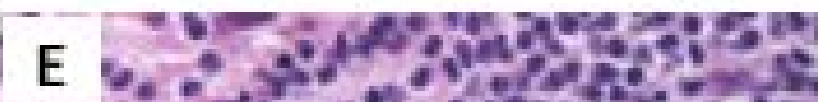

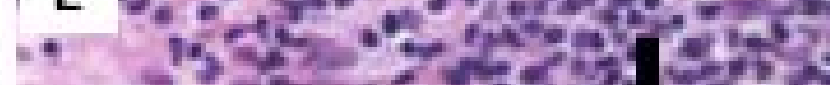
2. $, 7,5 \cdot 20,2 w 3$

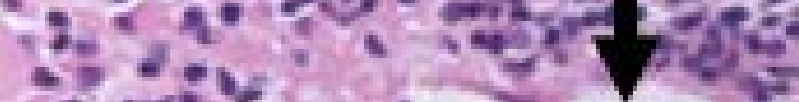
$y \leq v$ $\because 8,5-\xi_{0}, 2$. $\because y^{*} \div 3,205 y^{2}=$

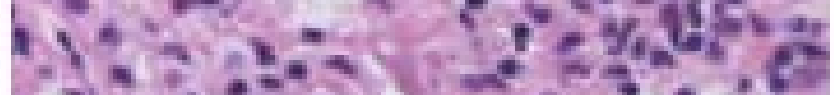

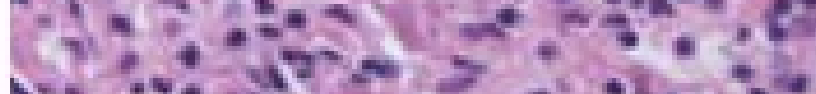

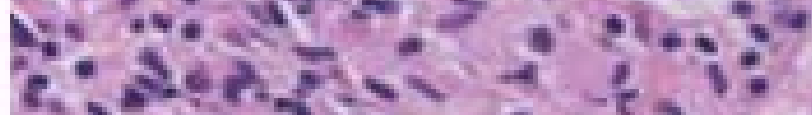

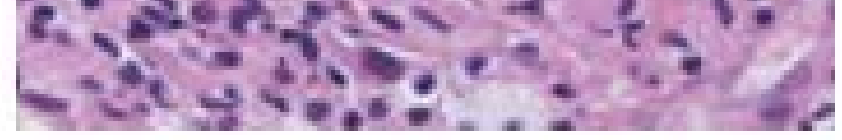
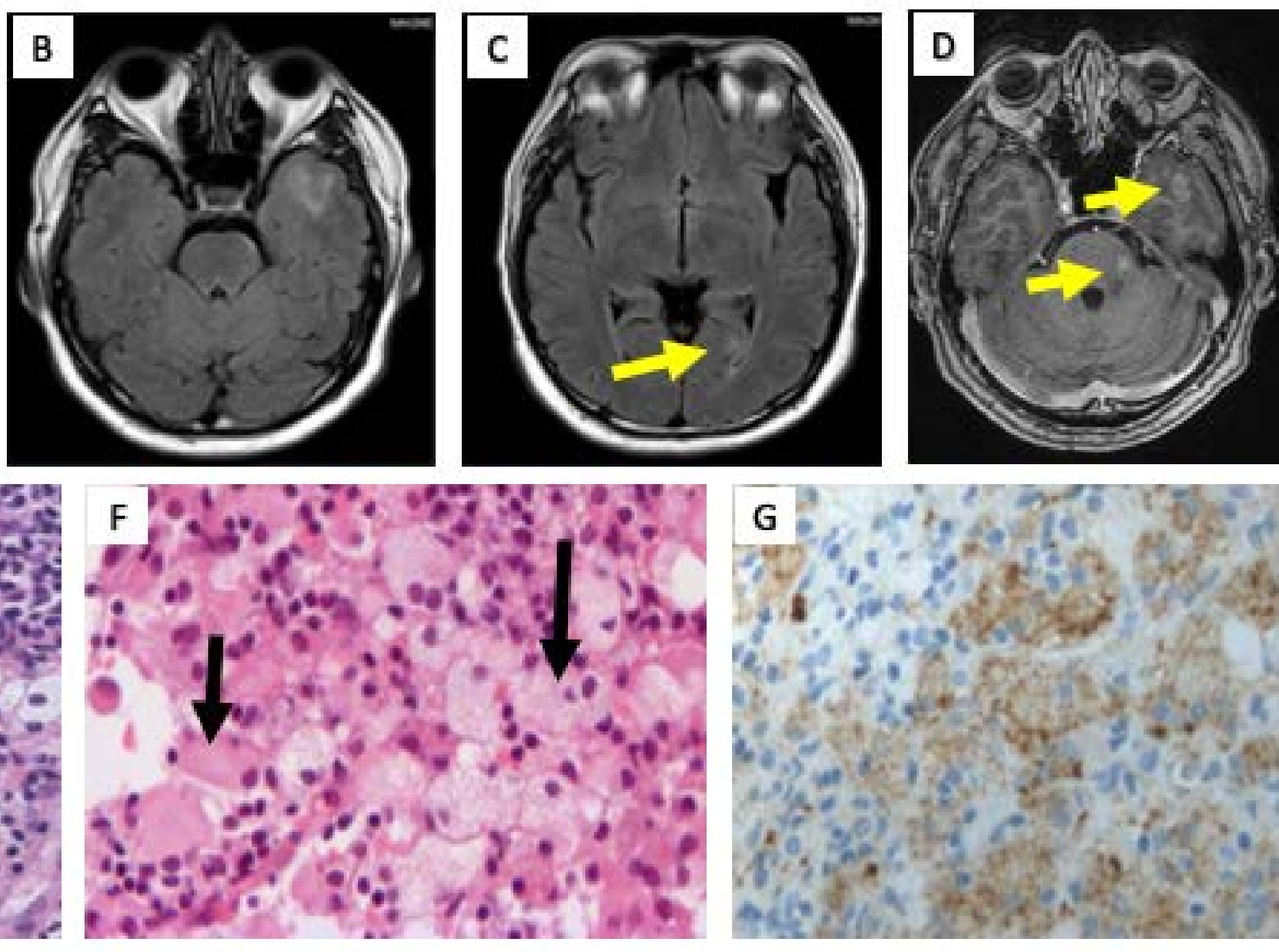